JAWABAN SOAL UTS 2018/2019 MATAKULIAH TEORI PEMROGRAMAN BORLAND DELPHI

\title{
DONI WINATA
}

16510085

Fakultas Komputer, 4487571-97

doniwinata.student@umitra.ac.id

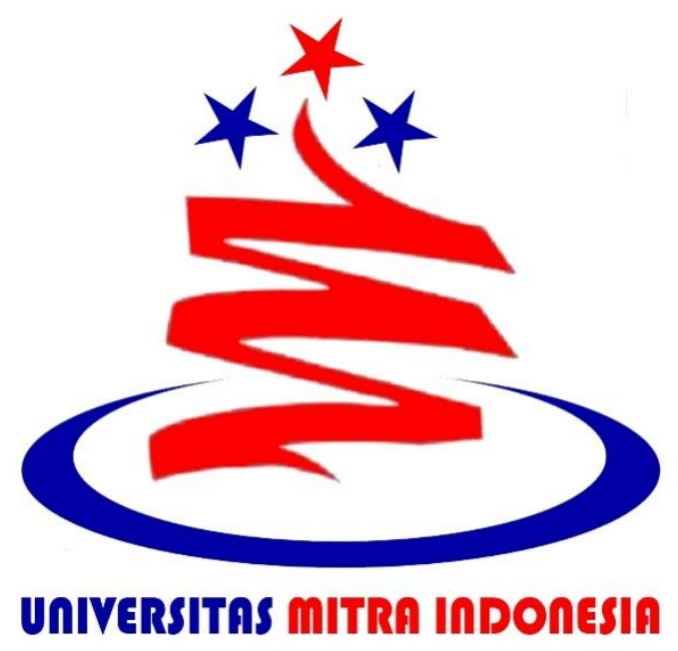




\section{A. STUDI KASUS ( SK )}

Pertanyaan Type C :

Pilihlah salah satu logo software anggota tim dipaparkan dan di jelaskan.

Jawaban :

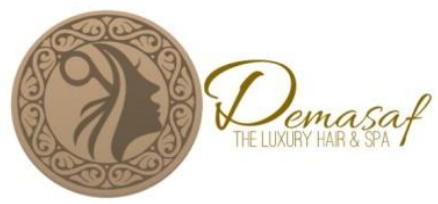

Pegangan gunting yang terdapat pada logo tersebut menggambarkan bahwa DEMASAF adalah salon yang berkompeten dibidangnya yaitu tata kecantikan rambut.

$>$ Terdapat siluet wajah wanita dan rambut di logo tersebut menunjukkan bahwa DEMASAF adalah salon khusus wanita.

Border lingkaran yang ada di sisi logo menggambarkan kesan mewah karna salon DEMASAF adalah salon yang mengusung kemewahan.
Warna gold (emas) yang diberikan pada logo menunjukkan kesan mewah dan berkelas, warna emas juga memiliki makna kesuksesan, kemenangan dan juga kemakmuran.

\section{B. STUDI REFERENSI ( SP )}

Pertanyaan Jenis B :

Carilah Perbedaan Utama Borland Delphi 6.0 dan Borland Delphi Embarcadero.

Jawaban :

\section{$>$ Borland delphi 6}

di rilis pada tahun 2001, Borland delphi 6.0 melakukan revitalisasi turbo pascal 6.0 dan menggerakkan form software yang menuju pemogramanpemograman yang berorientasi pada objek yang menarik produk borland pascal 7.0 (with objek). Upaya untuk mendukung linux dan windows untuk platform pengembangan lintas dibuat, dan sebuah platform alternatif yang menyeberang ke VCL dikenal sebagai CLX dikirim pada tahun 2002 dengan merilis delphi 6. Ini adalah upaya ke 
dua untuk menambahkan linux dengan keluarga produk delphi. Sejak CLX di buat sebelum delphi 6 , set vitur yang didasarkan pada VCL 5 yang menciptakan beberapa kerugian bagi CLX yang tidak memiliki beberapa fitur dibandingkan dengan VCL 6 dikirimkan dengan delphi 6.

\section{Borland Delphi Embarcadero}

Embarcadero devisi sebelumnya milik borland. Bahasa delphi atau dikenal sebagai objek pascal pada mulanya ditujukan hanya untuk platform microsoft windows naman saat ini telah mampu digunakan untuk mengembangkan aplikasi untuk berbagai platform seperti Mac OS X, iOS, android. Pada tanggal 8 Februari 2006, Borland mengumumkan akan melepas seluruh jajaran produk pengembangan aplikasi komputernya termasuk di antaranya Delphi, untuk itulah Borland membentuk perusahaan baru dengan nama CodeGear sehingga terpisah dari Borland.

\section{STUDI PENALARAN ( SP )}

Pertanyaan Kategori 3 :

Buatlah algoritma sederhana menggunakan flowchart (Pembayaran Kuliah Kampus Anda)

Jawaban :

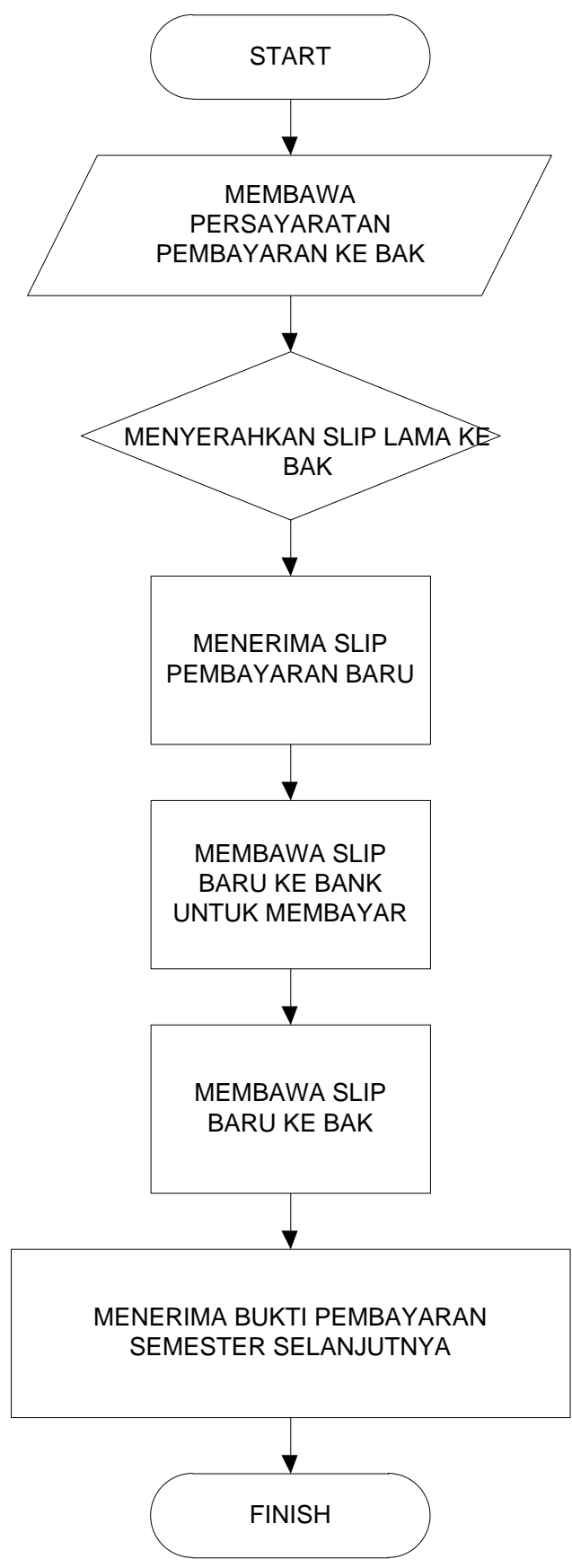


D. REFERENSI

[1] A. S. Putra And O. M. Febriani, "Knowledge Management Online Application In Pdam Lampung Province," In Prosiding International Conference On Information Technology And Business (Icitb), 2018, Pp. 181-187.

[2] A. S. Putra, O. M. Febriani, And B. Bachry, "Implementasi Genetic Fuzzy System Untuk Mengidentifikasi Hasil Curian Kendaraan Bermotor Di Polda Lampung," J. Sist. Inf. Dan Manaj. Basis Data, Vol. 1, No. 1, Pp. 21-30, 2018.

[3] O. M. Febriani And A. S. Putra, "Sistem Informasi Monitoring Inventori Barang Pada Balai Riset Standardisasi Industri Bandar Lampung," J. Inform., Vol. 13, No. 1, Pp. 90-98, 2014.

[4] Putra, Arie Setya. "2018 Artikel Struktur Data, Audit Dan Jaringan Komputer." (2018).

[5] Putra, A. S. (2018, July 17). Paperplain Fundamental Create Application With Borland
Delphi 7.0 University Of Mitra Indonesia. Retrieved From Osf.Io/Pbrn9. 